\title{
EVALUASI KINERJA JARINGAN JALAN PANGERAN TRUNOJOYO KOTA PAMEKASAN
}

\section{NETWORK OF ROAD PERFOMANCE EVALUATION PANGERAN TRUNOJOYO PAMEKASAN CITY}

\author{
Khoirul Abadi ${ }^{1}$, Andi Syaiful Amal ${ }^{2}$, Tommy Sumardi ${ }^{3}$ \\ ${ }^{123}$ Alumni Jurusan Teknik Sipil Fakultas Teknik - Univ.Muhammadiyah Malang \\ Kampus III Jl. Tlogomas No 246 Telp (0341) 464318-319 pes.130 Fax (0341) 460435 \\ Alamat korespondensi \\ e-mail : tommytiiforst@yahoo.co.id
}

\begin{abstract}
Network of road Pangeran Trunojoyo Pamekasan is one of the area located in the centre of community activity which are contained roads and signalized three intersection. The land use form for along way in Pangeran Trunojoyo are commerce area, public service and education area. The community activity gives influence for the movement traffic flow in network of road Pangeran Trunojoyo. The study purpose is to know about the network of road performance in Pangeran Trunojoyo road Pamekasan at this time. The method of this study based on Indonesian Highway Capacity Manual 1997 about urban roads and signalized intersection. Based on the study result in the peak hour at 06.45 - 07.45 a.m with the roads performance Pangeran Trunojoyo Corridor 1 (2/2 TB) degree of saturation (DS) 0,59 with the actual speed (V) $35 \mathrm{~km} / \mathrm{hour}$, while roads performance Pangeran Trunojoyo corridor 2 (4/2 B) value (DS) 0.30 with (V) $50 \mathrm{~km} / \mathrm{hour}$ lane 1 (South - North) and value DS 0.29, V $56 \mathrm{~km} / \mathrm{hour}$ lane 2 (North - South). Signalized three intersection performance value on South approach (DS) 0,71 with queue as long as $(Q L) 55.00$ metres.
\end{abstract}

Keywords: Network of Road, Roads, Three Way Intersection

\begin{abstract}
Abstrak
Jaringan jalan Pangeran Trunojoyo Kota Pamekasan merupakan salah satu kawasan yang berada di pusat kegiatan masyarakat yang terdapat ruas jalan dan simpang tiga bersinyal. Tata guna lahan sepanjang jalan Pangeran Trunojoyo berupa kegitan perdagangan, jasa dan pendidikan. Aktifitas masyarakat memberikan pengaruh terhadap pergerakan arus lalu lintas pada jaringan jalan Pangeran Trunojoyo. Tujuan dilakukan studi untuk mengetahui kinerja jaringan jalan di ruas jalan Pangeran Trunojoyo Kota Pamekasan pada saat ini. Metode studi ini mengacu Manual Kapasitas Jalan Indonesia Tahun 1997 dengan pembahasan ruas jalan perkotaan dan simpang bersinyal. Berdasarkan hasil studi jam puncak di ruas jalan Pangeran Trunojoyo terjadi pukul 06.45 - 07.45 dengan kinerja ruas jalan koridor 1 (2/2 TB) nilai derajat kejenuhan (DS) 0,59, dengan kecepatan sesungguhnya (V) $35 \mathrm{~km} / \mathrm{jam}$, sedangkan kinerja ruas jalan koridor 2 (4/2 B) nilai (DS) 0.30 , dengan (V) $50 \mathrm{~km} / \mathrm{jam}$ pada jalur 1 (S - U) dan nilai DS $0.29, \mathrm{~V} 56 \mathrm{~km} / \mathrm{jam}$ pada jalur 2 (U - S). Kinerja simpang tiga bersinyal nilai (DS) maksimum 0.71 terjadi pada pendekat Selatan, dengan panjang antrian (QL) $55.00 \mathrm{~m}$.
\end{abstract}

Kata kunci: Jaringan Jalan, Ruas Jalan, Simpang Tiga Bersinyal

\section{PENDAHULUAN}

Kota Pamekasan merupakan salah satu kota di Pulau Madura yang sedang berkembang. Tidak beda dengan kota/kabupaten lain di Madura, Kota Pamekasan memiliki peranan dalam berbagai kegiatan pembangunan dalam bidang ekonomi, pendidikan, industri dan distribusi bagi kemajuan Pulau Madura. Oleh karena itu, Kota Pamekasan dituntut memiliki sarana dan prasarana transportasi yang memadai agar tercipta kondisi lalu lintas yang lancar dan aman guna mendukung berbagai kegiatan yang ada. Kota Pamekasan pada tahun 2015 memiliki jumlah penduduk 186.385 jiwa (Sumber: Dinas Kependudukan dan Pencatatan Sipil Kabupaten Pamekasan) yang merupakan kota terpadat di Pulau Madura yang tiap tahunnya mengalami peningkatan dalam hal jumlah penduduk.

Sistem Transportasi di Kota Pamekasan berupa transportasi Moda Jalan 
Raya yang terdiri dari sistem jaringan jalan Pangeran Trunojoyo dan 3 terminal angkutan penumpang umum yaitu Terminal Ceguk, Terminal Lawangan Daya, dan Terminal Bugih. Sarana angkutan umum penumpang terdiri dari: MPU angkutan antar kota, Bus AKAP dan Bus AKDP. Angkutan pedesaan dan angkutan lingkungan berupa ojek, dan becak. Adapun untuk angkutan barang, layanan angkutan barang melewati jaringan jalan yang ada di Kota Pamekasan, yang menghubungkan Kota Sumenep di sebelah Timur Kota Pamekasan, Kota Sampang dan Kota Bangkalan di sebelah Barat Kota Pamekasan.

Sistem jaringan jalan Pangeran Trunojoyo meliputi ruas jalan koridor 1 tipe jalan 2 lajur 2 jalur tak terbagi $(2 / 2 \mathrm{~TB})$ dengan panjang jalan $640 \mathrm{~m}$, ruas jalan koridor 2 tipe jalan 4 lajur 2 jalur terbagi ( $4 / 2$ B) dengan panjang jalan $800 \mathrm{~m}$. Sedangkan total panjang $1,6 \mathrm{~km}$ pada ruas jalan Pangeran Trunojoyo terdapat 1 simpang tiga bersinyal.

Kondisi jaringan jalan Pangeran Trunojoyo dengan fungsi guna lahan berupa daerah komersil atau pelayanan umum pada ruas jalan koridor $1(2 / 2 \mathrm{~TB})$ dan simpang tiga bersinyal. Sedangkan ruas jalan koridor 2 (4/2 B) dengan fungsi guna lahan berupah daerah pemukiman. Jaringan jalan Pangeran Trunojoyo salah satu akses utama yang berada didaerah pusat kegiatan. Adanya kegiatan sekolah, perkantoran dan pusat perdagangan (pertokoan, apotek, bengkel mobil). Hal ini mengakibatkan kendaraan berhenti dan parkir di badan jalan tersebut. Parkir di badan jalan mengganggu aktifitas masyarakat, bahkan mempersempit lebar lajur atau jalur. Kondisi inilah yang menyebabkan pergerakan arus lalulintas jaringan jalan di ruas jalan Pangeran Trunojoyo terhambat.

Studi ini dilakukan untuk mengetahui kinerja jaringan jalan Pangeran Trunojoyo Kota Pamekasan saat ini yang meliputi ruas jalan $2 / 2 \mathrm{~TB}$, ruas jalan $4 / 2 \mathrm{~B}$ dan simpang tiga bersinyal.

\section{METODE PENELITIAN}

Lokasi studi berupa jaringan jalan Pangeran Trunojoyo yang meliputi ruas jalan Jl. Pangeran Trunojoyo koridor 1 (STA $0+$ 360 s.d STA $0+560) 2$ lajur 2 jalur tak terbagi $(2 / 2$ TB) dan ruas Jl. Pangeran
Trunojoyo koridor 2 (STA $1+220$ s.d STA 1 $+420) 4$ lajur 2 jalur terbagi (4/2 B). Sedangkan simpang tiga bersinyal meliputi Jl. Pangeran Trunojoyo (Pendekat Selatan) Jl. Pangeran Trunojoyo (Pendekat Utara) -Jl. Abdul Aziz (Pendekat Barat 1) -Jl. Teja Timur (Pendekat Barat 2).

\section{Tahapan Studi}

Tahapan studi disajikan pada gambar 1 .

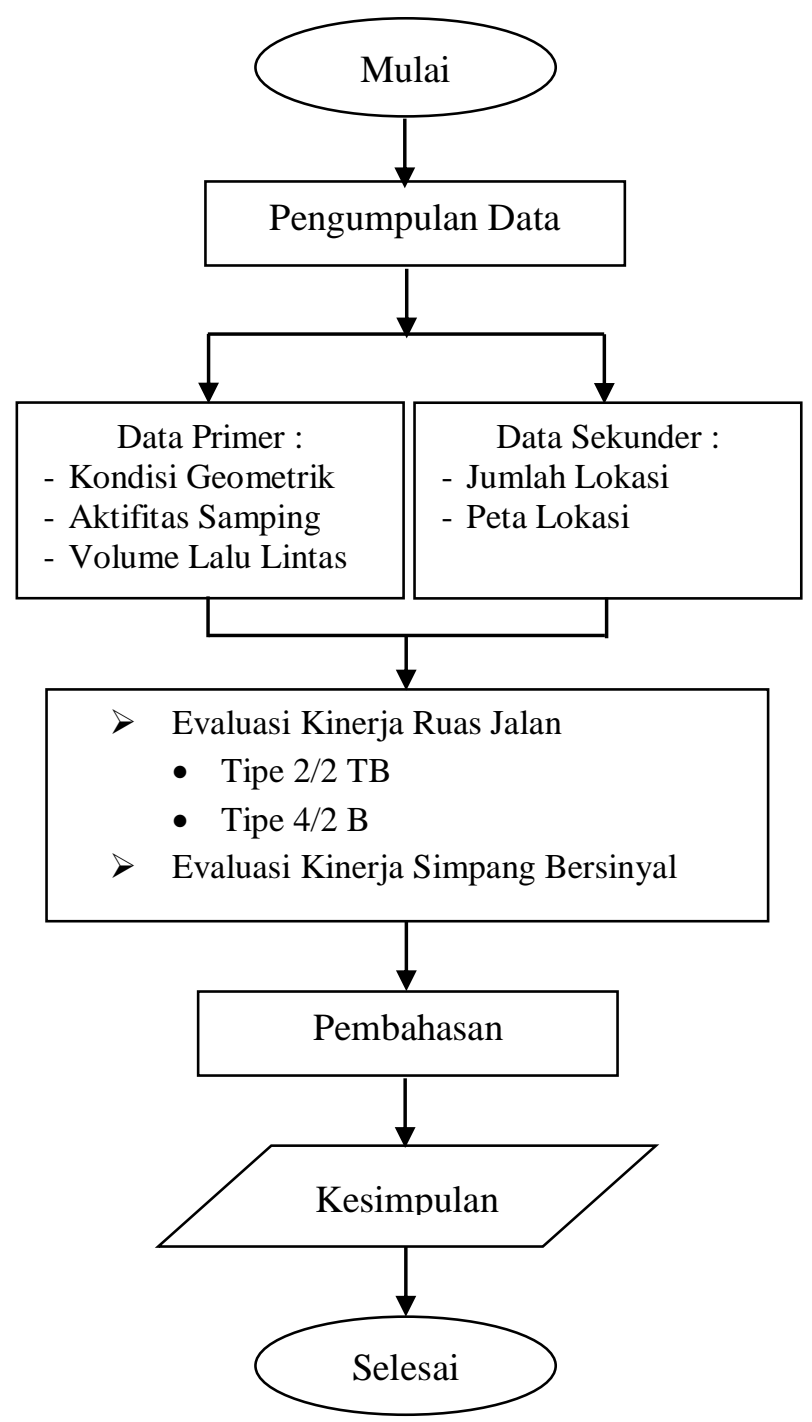

Gambar 1. Diagram Alir Studi

Evaluasi kinerja jaringan jalan Pangeran Trunojoyo yang meliputi ruas jalan $2 / 2 \mathrm{~TB}$, ruas jalan $4 / 2 \mathrm{~B}$ dengan pokok bahasan ruas jalan perkotaan dan simpang tiga bersinyal mengacu Manual Kapasitas Jalan Indonesia : Tahun 1997 yang diterbitkan oleh Direktorat Jendral Bina Marga. 


\section{HASIL DAN PEMBAHASAN \\ Kondisi Geometrik}

Kondisi geometrik dan karakteristik jaringan Jl. Pangeran Trunojoyo pada lokasi studi meliputi ruas Jl. Pangeran Trunojoyo Koridor $1(2 / 2 \mathrm{~TB})$ lebar perkerasan $11 \mathrm{~m}$, panjang jalan $640 \mathrm{~m}$, lebar parkir 2,5 m, lebar jalur lalulintas efektif $8,5 \mathrm{~m}$. Ruas $\mathrm{Jl}$. Pangeran Trunojoyo Koridor 2 (4/2 B) lebar perkerasan $16 \mathrm{~m}$, panjang jalan $600 \mathrm{~m}$, lebar parkir $1,5 \mathrm{~m}$, lebar jalur lalulintas efektif jalur 1 (Selatan) 6,5 $\mathrm{m}$ dan jalur 2 (Utara) $8 \mathrm{~m}$. Sedangkan simpang tiga bersinyal pada Jl. Pangeran Trunojoyo (Pendekat Selatan) lebar perkerasan kanan $8 \mathrm{~m}$ dan kiri $8 \mathrm{~m}$, lebar efektif $\left(\mathrm{W}_{\text {masuk }}\right) 8 \mathrm{~m}$. Jl. Pangeran Trunojoyo (Pendekat Utara) lebar perkerasan kanan $8 \mathrm{~m}$ dan kiri $8 \mathrm{~m}$, lebar efektif $\left(\mathrm{W}_{\text {masuk }}\right) 3,5 \mathrm{~m}$. Jl. Abdul Aziz (Pendekat Barat 1) lebar perkerasan kanan $5 \mathrm{~m}$ dan kiri $5 \mathrm{~m}$, lebar efektif $\left(\mathrm{W}_{\text {masuk }}\right) 5 \mathrm{~m}$. Jl. Teja Timur (Pendekat Barat 2) lebar perkerasan kanan 5,5 $\mathrm{m}$ dan kiri 5,5 m, lebar efektif $\left(\mathrm{W}_{\text {masuk }}\right) 5,5 \mathrm{~m}$. Selengkapnya divisualisasikan pada gambar 2.

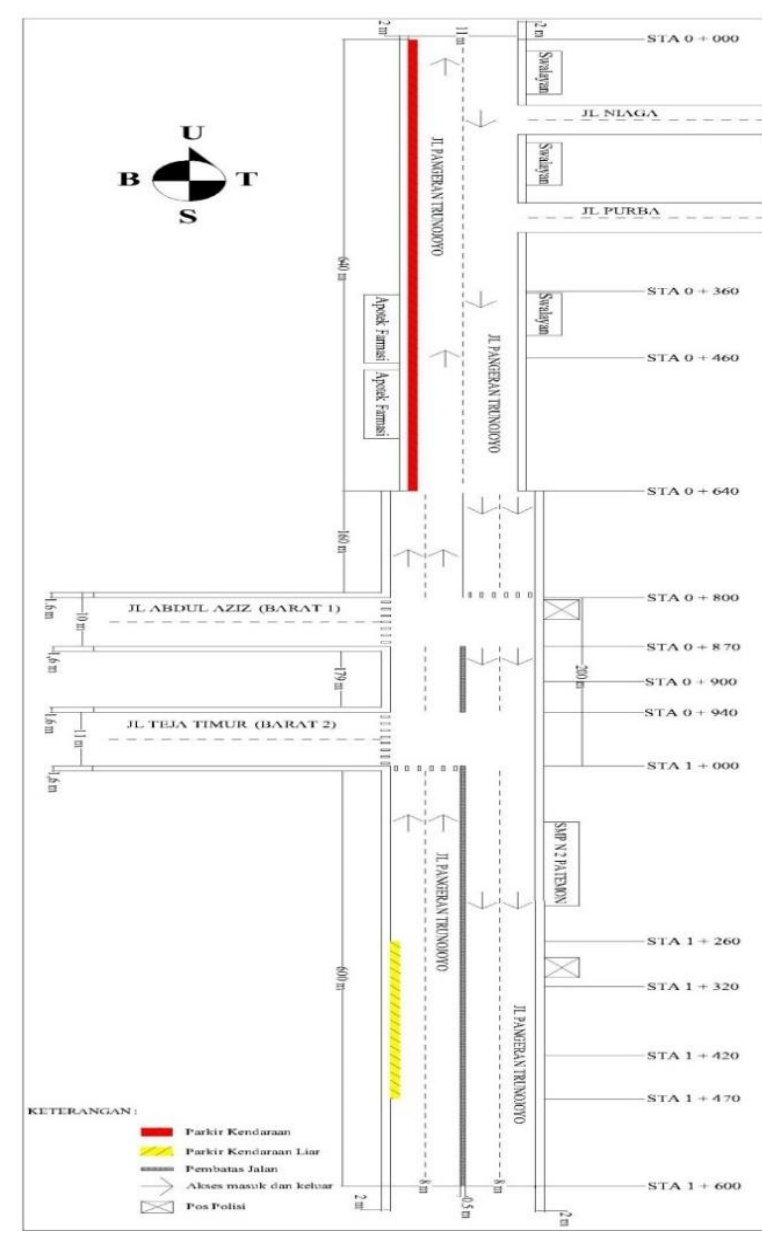

Gambar 2. Geometrik Ruas Jalan dan Simpang Tiga Bersinyal

\section{Volume Arus Lalu-lintas}

Volume arus

lalu-lintas

dikelompokkan menjadi dua yaitu pada jam puncak pagi dan jam puncak sore, hal ini terkait dengan aktifitas pada jaringan $\mathrm{Jl}$. Pangeran Trunojoyo. Pada saat pagi adanya kegiatan sekolah, pekantoran sedangkan pada saat siang-sore adanya kegiatan perekonomian (pertokoan, apotek, bengkel mobil).

Jam puncak ruas jalan dan simpang tiga bersinyal saat pagi terjadi pukul 06.4507.45 sedangkan pada jam puncak sore terjadi pukul 16.30-17.30. Adapun volume arus lalu lintas pada Jl. Pangeran Trunojoyo Koridor $1(2 / 2 \mathrm{~TB})$ disajikan pada tabel 1 , volume arus lalu-lintas pada Jl. Pangeran Trunojoyo Koridor 2 (4/2 B) disajikan pada tabel 2. Sedangkan volume arus lalu-lintas pada simpang tiga bersinyal jam puncak pagi disajikan pada tabel 3 dan volume arus lalulintas pada jam puncak sore disajikan pada tabel 4.

Tabel 1. Volume Arus LaluLintas Jalan Pangeran Trunojoyo Koridor 1 (2/2 TB) Pada Jam Puncak



Sumber : Hasil Survey

Tabel 2. Volume Arus LaluLintas Jalan Pangeran Trunojoyo Koridor 2 (4/2 B) Pada Jam Puncak

\begin{tabular}{|c|c|c|c|c|c|c|c|}
\hline & \multirow{2}{*}{ Uraian } & \multicolumn{3}{|c|}{ Arah $1(\mathrm{~S}-\mathrm{U})$} & \multicolumn{3}{|c|}{ Arah $2(\mathrm{U}-\mathrm{S})$} \\
\hline & & LV & $\mathrm{HV}$ & $\mathrm{MC}$ & LV & HV & $\mathrm{MC}$ \\
\hline 50 & Jumlah (kend/jam) & 598 & 6 & 1068 & 614 & 12 & 1197 \\
\hline 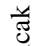 & Tot (kend /jam) & & 1672 & & & 1823 & \\
\hline ే & Tot (smp/jam) & & 872.2 & & & 927.65 & \\
\hline $\begin{array}{l}0 \\
\text { ڤ్ }\end{array}$ & Jumlah (kend/jam) & 621 & 8 & 876 & 597 & 7 & 1210 \\
\hline ב & Tot (kend /jam) & & 1505 & & & 1814 & \\
\hline ప్త & Tot (smp/jam) & & 849.6 & & & 907.9 & \\
\hline
\end{tabular}

Sumber : Hasil Survey 
Tabel 3. Volume Arus LaluLintas Pada Simpang Tiga Bersinyal Jam Puncak Pagi

\begin{tabular}{|c|c|c|c|c|c|c|}
\hline \multirow{3}{*}{ Uraian } & \multicolumn{6}{|c|}{ Pendekat Utara Jl. Pangeran Trunojoyo } \\
\hline & \multicolumn{3}{|c|}{ STOR } & \multicolumn{3}{|c|}{ RT } \\
\hline & LV & HV & $\mathrm{MC}$ & LV & $\mathrm{HV}$ & $\mathrm{MC}$ \\
\hline Jumlah (kend/jam) & 541 & 5 & 715 & 47 & 4 & 62 \\
\hline Tot (kend/jam) & & 1261 & & & 113 & \\
\hline Tot (smp/jam) & & 690.5 & & & 64.2 & \\
\hline \multirow{3}{*}{ Uraian } & \multicolumn{6}{|c|}{ Pendekat Selatan J1. Pangeran Trunojoyo } \\
\hline & \multicolumn{3}{|c|}{ LT } & \multicolumn{3}{|c|}{ ST } \\
\hline & LV & $\mathrm{HV}$ & $\mathrm{MC}$ & LV & $\mathrm{HV}$ & $\mathrm{MC}$ \\
\hline Jumlah (kend/jam) & 35 & 1 & 53 & 559 & 5 & 1015 \\
\hline Tot (kend/jam) & & 89 & & & 1558 & \\
\hline Tot (smp/jam) & & 47.3 & & & 769 & \\
\hline $\mathrm{Q}_{\text {TOTAL }}$ & \multicolumn{6}{|c|}{816.3} \\
\hline \multirow{3}{*}{ Uraian } & \multicolumn{6}{|c|}{ Pendekat Barat $1 \mathrm{Jl}$. Abdul Aziz } \\
\hline & \multicolumn{3}{|c|}{ LT } & \multicolumn{3}{|c|}{ RT } \\
\hline & LV & HV & $\mathrm{MC}$ & LV & HV & $\mathrm{MC}$ \\
\hline Jumlah (kend/jam) & 48 & 2 & 179 & 117 & 3 & 555 \\
\hline Tot (kend/jam) & & 229 & & & 675 & \\
\hline Tot (smp/jam) & & 86.6 & & & 231.9 & \\
\hline $\mathrm{Q}_{\text {TOTAL }}$ & \multicolumn{6}{|c|}{318.5} \\
\hline \multirow{3}{*}{ Uraian } & \multicolumn{6}{|c|}{ Pendekat Barat $2 \mathrm{Jl}$. Teja Timur } \\
\hline & \multicolumn{3}{|c|}{ LT } & \multicolumn{3}{|c|}{ RT } \\
\hline & LV & HV & $\mathrm{MC}$ & LV & HV & $\mathrm{MC}$ \\
\hline Jumlah (kend/jam) & 71 & 5 & 209 & 96 & 3 & 198 \\
\hline Tot (kend/jam) & & 285 & & & 297 & \\
\hline Tot (smp/jam) & & 119.5 & & & 139.9 & \\
\hline $\mathrm{Q}_{\text {TOTAL }}$ & \multicolumn{6}{|c|}{259.4} \\
\hline
\end{tabular}

Sumber : Hasil Survey

Tabel 4. Volume Arus LaluLintas Pada Simpang Tiga Bersinyal Jam Puncak Sore

\begin{tabular}{|c|c|c|c|c|c|c|}
\hline \multirow{3}{*}{ Uraian } & \multicolumn{6}{|c|}{ Pendekat Utara Jl. Pangeran Trunojoyo } \\
\hline & \multicolumn{3}{|c|}{ STOR } & \multicolumn{3}{|c|}{ RT } \\
\hline & LV & HV & $\mathrm{MC}$ & LV & $\mathrm{HV}$ & MC \\
\hline Jumlah (kend/jam) & 526 & 6 & 604 & 49 & 7 & 55 \\
\hline Tot (kend/jam) & & 1136 & & & 111 & \\
\hline Tot (smp/jam) & & 654.6 & & & 69.1 & \\
\hline \multirow{3}{*}{ Uraian } & \multicolumn{6}{|c|}{ Pendekat Selatan J1. Pangeran Trunojoyo } \\
\hline & \multicolumn{3}{|c|}{ LT } & \multicolumn{3}{|c|}{ ST } \\
\hline & LV & $\mathrm{HV}$ & $\mathrm{MC}$ & LV & $\mathrm{HV}$ & MC \\
\hline Jumlah (kend/jam) & 57 & 1 & 51 & 564 & 7 & 825 \\
\hline Tot (kend/jam) & & 109 & & & 1396 & \\
\hline Tot (smp/jam) & & 68.5 & & & 738.1 & \\
\hline $\mathrm{Q}_{\text {TOTAL }}$ & \multicolumn{6}{|c|}{806.6} \\
\hline \multirow{3}{*}{ Uraian } & \multicolumn{6}{|c|}{ Pendekat Barat $1 \mathrm{Jl}$. Abdul Aziz } \\
\hline & \multicolumn{3}{|c|}{ LT } & \multicolumn{3}{|c|}{ RT } \\
\hline & LV & $\mathrm{HV}$ & $\mathrm{MC}$ & LV & $\mathrm{HV}$ & $\mathrm{MC}$ \\
\hline Jumlah (kend/jam) & 50 & 4 & 134 & 97 & 3 & 628 \\
\hline Tot (kend/jam) & & 188 & & & 728 & \\
\hline Tot (smp/jam) & & 82 & & & 226.5 & \\
\hline $\mathrm{Q}_{\text {TOTAL }}$ & \multicolumn{6}{|c|}{308.5} \\
\hline \multirow{3}{*}{ Uraian } & \multicolumn{6}{|c|}{ Pendekat Barat $2 \mathrm{Jl}$. Teja Timur } \\
\hline & \multicolumn{3}{|c|}{ LT } & \multicolumn{3}{|c|}{ RT } \\
\hline & LV & $\mathrm{HV}$ & $\mathrm{MC}$ & LV & $\mathrm{HV}$ & MC \\
\hline Jumlah (kend/jam) & 45 & 4 & 174 & 122 & 2 & 208 \\
\hline Tot (kend/jam) & & 223 & & & 332 & \\
\hline Tot (smp/jam) & & 85 & & & 166.2 & \\
\hline $\mathrm{Q}_{\text {TOTAL }}$ & \multicolumn{6}{|c|}{251.2} \\
\hline
\end{tabular}

Sumber : Hasil Survey

\section{Kinerja Ruas Jalan}

Pada ruas Jl. Pangeran Trunojoyo

Koridor $1(2 / 2 \mathrm{~TB})$ jam puncak pagi, volume arus lalu lintas total $1668.35 \mathrm{smp} / \mathrm{jam}$ dengan kelas hambatan samping rendah (L), kapasitas (C) 2799,55 smp/jam. Sedangkan pada jam puncak sore, volume arus lalu lintas total 1597.25 smp/jam dengan kelas hambatan samping sedang (M), kapasitas (C) 2712,96 smp/jam. Nilai derajat kejenuhan (DS) pada ruas Jl. Pangeran Trunojoyo koridor 1 (2/2 TB) pada jam puncak pagi derajat kejenuhan (DS) 0,59, kecepatan sesungguhnya (V) 35 $\mathrm{km} / \mathrm{jam}$ dan pada jam puncak sore derajat kejenuhan (DS) 0.58 , kecepatan sesungguhnya (V) $34 \mathrm{~km} / \mathrm{jam}$. Rangkuman kinerja ruas jalan Koridor 1 (2/2 TB) disajikan pada tabel 5.

Tabel 5. Kinerja Ruas Jalan Koridor 1 (2/2 TB) Pada Kondisi Eksisting

\begin{tabular}{|c|c|c|c|c|c|}
\hline Waktu & $\begin{array}{c}\mathrm{Q} \\
\mathrm{smp} / \mathrm{ja} \\
\mathrm{m}\end{array}$ & $\begin{array}{c}\mathrm{FV} \\
\mathrm{km} / \mathrm{jam}\end{array}$ & $\begin{array}{c}\mathrm{C} \\
\mathrm{smp} / \mathrm{jam}\end{array}$ & DS & $\begin{array}{c}\mathrm{V} \\
\mathrm{km} / \mathrm{jam}\end{array}$ \\
\hline Jam Puncak Pagi & 1668.35 & 42.83 & 2799.55 & 0.59 & 35 \\
\hline Jam Puncak Sore & 1597.25 & 41.52 & 2712.96 & 0.58 & 34 \\
\hline
\end{tabular}

Sumber : Hasil Survey

Ruas Jl. Pangeran Trunojoyo koridor 2 (4/2 B) pada jam puncak pagi dengan lebar jalur lalu lintas efektif $(\mathrm{Wc})$, jalur 1 (S - U) $6.50 \mathrm{~m}(3.25 \mathrm{~m} / \mathrm{lajur})$, maka nilai $\mathrm{FVw}$ pada jalur $1(\mathrm{~S}-\mathrm{U})=-2 \mathrm{~km} / \mathrm{jam}$. Sedangkan untuk jalur $2(\mathrm{U}-\mathrm{S}) 8.00 \mathrm{~m}$ (4.00 m/lajur), maka nilai $\mathrm{FVw}$ pada jalur $2(\mathrm{U}-\mathrm{S})=4 \mathrm{~km} / \mathrm{jam}$. Pada jam puncak pagi volume arus lalu lintas (Q) $872.20 \mathrm{smp} / \mathrm{jam}$ jalur 1 (S - U), Q 972.65 smp/jam jalur $2(\mathrm{U}-\mathrm{S})$ dengan masingmasing jalur kelas hambatan samping rendah (L), pada jam puncak sore arus lalu lintas (Q) $849.60 \mathrm{smp} / \mathrm{jam}$ jalur 1 (S - U), Q 907.90 smp/jam jalur 2 (U - S) dengan masingmasing jalur kelas hambatan samping rendah (L). Berdasarkan lebar jalur lalulintas efektif kapasitas 2851,20 smp/jam jalur 1 (S - U) dan kapasitas 3207,60 smp/jam jalur 2 (U - S). Nilai derajat kejenuhan (DS) pada ruas Jl. Pangeran Trunojoyo koridor 2 (4/2 B) pada jam puncak pagi derajat kejenuhan (DS) 0,30 dengan kecepatan sesungguhnya (V) 50 $\mathrm{km} / \mathrm{jam}$ jalur 1 (S - U), DS 0,29 dengan V 56 $\mathrm{km} / \mathrm{jam}$ jalur 2 (U - S). Sedangkan pada jam puncak sore derajat kejenuhan (DS) 0.29 dengan V $51 \mathrm{~km} / \mathrm{jam}$ jalur 1 (S - U), DS 0.28 dengan V $56 \mathrm{~km} / \mathrm{jam}$ jalur $2(\mathrm{U}-\mathrm{S})$. Rangkuman kinerja ruas jalan Koridor 2 (4/2 B) disajikan pada tabel 6 . 
Tabel 6. Kinerja Ruas Jalan Koridor 2 (4/2 B) Pada Kondisi Eksisting

\begin{tabular}{|c|c|c|c|c|c|c|}
\hline Waktu & Jalur & $\begin{array}{c}\mathrm{Q} \\
\mathrm{smp} / \mathrm{ja} \\
\mathrm{m}\end{array}$ & $\begin{array}{c}\mathrm{FV} \\
\mathrm{km} / \mathrm{jam}\end{array}$ & smp/jam & DS & $\begin{array}{c}\mathrm{V} \\
\mathrm{km} / \mathrm{jam}\end{array}$ \\
\hline \multirow{2}{*}{ Jam Puncak Pagi } & $1(\mathrm{~S}-\mathrm{U})$ & 872.20 & 51.15 & 2851.20 & 0.30 & 50 \\
\hline & $2(U-S)$ & 972.65 & 56.73 & 3207.60 & 0.29 & 56 \\
\hline \multirow{2}{*}{ Jam Puncak Sore } & $1(\mathrm{~S}-\mathrm{U})$ & 849.60 & 51.15 & 2851.20 & 0.29 & 51 \\
\hline & $2(U-S)$ & 907.90 & 56.73 & 3207.60 & 0.28 & 56 \\
\hline
\end{tabular}

Sumber : Hasil Survey

\section{Kinerja Simpang Tiga Bersinyal}

Lebar efektif $\left(\mathrm{W}_{\text {masuk }}\right)$ pendekat Selatan $=8.00 \mathrm{~m}$, pendekat Utara $=3.50 \mathrm{~m}$, pendekat Barat $1=5.00 \mathrm{~m}$, pendekat Barat 2 $=5.50 \mathrm{~m}$. Sedangkan hambatan samping pada jam puncak pagi untuk pendekat Selatan dan pendekat Utara $=0.94$, pendekat Barat 1 $=0.92$, pendekat Barat $2=0.89$ dan jam puncak sore pendekat Selatan $=0.94$, pendekat Utara $=0,92$, pendekat Barat 1 dan pendekat Barat $2=0.92$. Kapasitas (C) masing-masing pendekat di simpang tiga bersinyal pada jam puncak pagi, Jl. Pangeran Trunojoyo (Pendekat Utara) $\mathrm{C}=351$ smp/jam, Jl. Pangeran Trunojoyo (Pendekat Selatan) $\mathrm{C}=1153 \mathrm{smp} / \mathrm{jam}$, Jl. Abdul Aziz (Pendekat Barat 1) C = 549 smp/jam, Jl. Teja Timur (Pendekat Barat 2) $\mathrm{C}=548 \mathrm{smp} / \mathrm{jam}$. Sedangkan pada jam puncak sore, Jl. Pangeran Trunojoyo (Pendekat Utara) $\mathrm{C}=$ 343 smp/jam, Jl. Pangeran Trunojoyo (Pendekat Selatan) $\mathrm{C}=1165 \mathrm{smp} / \mathrm{jam}, \mathrm{Jl}$. Abdul Aziz (Pendekat Barat 1) $\mathrm{C}=549$ smp/jam, Jl. Teja Timur (Pendekat Barat 2) C $=594 \mathrm{smp} / \mathrm{jam}$. Kinerja simpang tiga bersinyal pada jam puncak pagi pendekat Utara derajat kejenuhan (DS) 0.18, panjang antrian (QL) $16.00 \mathrm{~m}$, tundaan total $\left(\mathrm{D}_{\mathrm{TOT}}\right)$ 1804 smp.det. Pendekat Selatan derajat kejenuhan (DS) 0.71, panjang antrian (QL) $55.00 \mathrm{~m}$, tundaan total $\left(\mathrm{D}_{\text {тот }}\right) 24060 \mathrm{smp}$.det. Pendekat Barat 1 derajat kejenuhan (DS) 0.58 , panjang antrian (QL) $44.00 \mathrm{~m}$, tundaan total $\left(\mathrm{D}_{\text {Тот }}\right) 10197$ smp.det. Pendekat Barat 2 derajat kejenuhan (DS) 0.47, panjang antrian (QL) $29.00 \mathrm{~m}$, tundaan total $\left(\mathrm{D}_{\text {Tот }}\right) 7839$ smp.det. Sedangkan kinerja simpang tiga bersinyal pada jam puncak sore pada pendekat Utara derajat kejenuhan (DS) 0.20, panjang antrian (QL) $18.00 \mathrm{~m}$, tundaan total (D $\left.\mathrm{D}_{\text {Tот }}\right) 1946$ smp.det. Pendekat Selatan derajat kejenuhan (DS) 0.69, panjang antrian (QL) $52.50 \mathrm{~m}$, tundaan total $\left(\mathrm{D}_{\text {Tот }}\right) 23332$ smp.det. Pendekat Barat 1 derajat kejenuhan
(DS) 0.56, panjang antrian (QL) $44.00 \mathrm{~m}$, tundaan total ( $\left.\mathrm{D}_{\text {тот }}\right) 9718$ smp.det. Pendekat Barat 2 derajat kejenuhan (DS) 0.42, panjang antrian (QL) $29.00 \mathrm{~m}$, tundaan total $\left(\mathrm{D}_{\text {TOT }}\right)$ 7477 smp.det. Rangkuman kinerja simpang tiga bersinyal pada jam puncak pagi dan jam puncak sore disajikan pada tabel 7 .

Tabel 7. Kinerja Simpang Tiga Bersinyal Pada Kondisi Eksisting

\begin{tabular}{|c|c|c|c|c|c|c|c|c|}
\hline & $\mathrm{P}$ & Q & & C & DS & QL & Nvs & DxQ \\
\hline & & smp/jam & $\begin{array}{c}\text { smp/jam } \\
\text { hijau }\end{array}$ & $\begin{array}{c}\text { smp/jam } \\
\text { hijau }\end{array}$ & & $\mathrm{m}$ & smp/jan & smp/jam \\
\hline \multirow{4}{*}{ 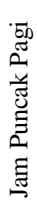 } & $\mathrm{U}$ & 64.2 & 1754 & 351 & 0.18 & 16 & 48 & 1804 \\
\hline & $\mathrm{S}$ & 816.3 & 3931 & 1153 & 0.71 & 55 & 688 & 24060 \\
\hline & B1 & 318.5 & 2746 & 549 & 0.58 & 44 & 267 & 10197 \\
\hline & B2 & 259.4 & 2740 & 548 & 0.47 & 29 & 203 & 7839 \\
\hline \multirow{4}{*}{ 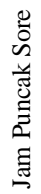 } & $\mathrm{U}$ & 69.1 & 1717 & 343 & 0.18 & 18 & 52 & 1946 \\
\hline & $\mathrm{S}$ & 806.6 & 3971 & 1165 & 0.71 & 52.5 & 670 & 23332 \\
\hline & B1 & 308.5 & 2746 & 549 & 0.58 & 44 & 256 & 9718 \\
\hline & B2 & 251.2 & 2970 & 594 & 0.47 & 29 & 197 & 7477 \\
\hline
\end{tabular}

\section{Pembahasan}

Jaringan jalan Pangeran Trunojoyo meliputi ruas jalan koridor $1(2 / 2 \mathrm{~TB})$, ruas jalan koridor 2 (4/2 B) simpang tiga bersinyal pada masing-masing pendekat. Fungsi guna lahan merupakan daerah komersil atau pelayanan umum pada ruas jalan koridor 1 $\left(\begin{array}{ll}2 / 2 & \text { TB}\end{array}\right)$ dan simpang tiga bersinyal. Sedangkan ruas jalan koridor $2(4 / 2$ B), fungsi guna lahan berupah daerah pemukiman. Adanya tata guna lahan berupa daerah komersil atau pelayanan umum dan pemukiman relatif tidak berpengaruh terhadap posisi ruas jalan koridor 1 (2/2 TB), ruas jalan koridor $2(4 / 2 \mathrm{~B})$ dan simpang tiga bersinyal pada masing-masing pendekat.

Berdasarkan volume arus lalulintas baik jam puncak pagi dan jam puncak sore terjadi bersamaan yaitu jam puncak pagi terjadi pukul 06.45-07.45 sedangkan pada jam puncak sore terjadi pukul 16.30-17.30 pada ruas jalan koridor 1 (2/2 TB), ruas jalan koridor 2 (4/2 B) dan simpang tiga bersinyal pada masing-masing pendekat, karena aktifitas di sepanjang ruas jalan koridor 1 $(2 / 2 \mathrm{~TB})$, ruas jalan koridor 2 (4/2 B) dan simpang tiga bersinyal pada masing-masing pendekat relatif sama. Jam puncak terjadi pada waktu yang sama meskipun ruas jalan koridor $1(2 / 2 \mathrm{~TB})$, ruas jalan koridor $2(4 / 2$ B) terpisah adanya simpang tiga bersinyal. 
Ini menunjukkan bahwa arus lalulintas relatif stabil dan aktifitas samping relatif kecil.

Operasional lampu lalu-lintas simpang tiga bersinyal relatif tidak berpengaruh terhadap volume arus lalulintas jalan ruas koridor $1(2 / 2 \mathrm{~TB})$, ruas jalan koridor 2 (4/2 B), karena arus lalulintas dari pendekat Barat, arus lalulintas pendekat Utara ke arus lalu lintas pendekat Barat dan arus lalu lintas pendekat Selatan ke arus lalu lintas pendekat Barat tidak mengganggu arus lalulintas pendekat Utara dan arus lalulintas pendekat Selatan.

Kinerja Ruas Jl. Pangeran Trunojoyo koridor $1(2 / 2 \mathrm{~TB})$ pada jam puncak pagi nilai derajat kejenuhan (DS) 0,59 dengan kecepatan sesungguhnya (V) $35 \mathrm{~km} / \mathrm{jam}$ dan pada jam puncak sore nilai derajat kejenuhan (DS) 0.58 dengan kecepatan sesungguhnya (V) $34 \mathrm{~km} / \mathrm{jam}$. Nilai derajat kejenuhan belum melebihi batas toleransi yang diizinkan dimana DS $<0,8$, masih relatif mampu melayani pergerakan arus lalu lintas ruas Jl. Pangeran Trunojoyo koridor $1(2 / 2$ $\mathrm{TB})$.

Kinerja ruas Jl. Pangeran Trunojoyo koridor 2 (4/2 B) pada jam puncak pagi nilai derajat kejenuhan (DS) 0.30 , dengan kecepatan sesungguhnya (V) $50 \mathrm{~km} / \mathrm{jam}$ pada jalur 1 (S - U) dan DS 0.29, V $56 \mathrm{~km} / \mathrm{jam}$ pada jalur 2 (U - S) dan pada jam puncak sore nilai derajat kejenuhan (DS) 0.29 , dengan kecepatan sesungguhnya (V) 51 $\mathrm{km} / \mathrm{jam}$ pada jalur 1 (S - U) dan DS 0.28, V $56 \mathrm{~km} / \mathrm{jam}$ pada jalur $2(\mathrm{U}-\mathrm{S})$. Nilai derajat kejenuhan belum melebihi batas toleransi yang diizinkan dimana DS $<0,8$, masih relatif mampu melayani pergerakan arus lalu lintas ruas Jl. Pangeran Trunojoyo koridor 2 $(4 / 2 \mathrm{~B})$.

Kinerja simpang tiga bersinyal pada masing masing pendekat pada jam puncak pagi pada pendekat Utara derajat kejenuhan (DS) 0.18, panjang antrian (QL) $16.00 \mathrm{~m}$. Pendekat Selatan derajat kejenuhan (DS) 0.71, panjang antrian (QL) $55.00 \mathrm{~m}$. Pendekat Barat 1 derajat kejenuhan (DS) 0.58 , panjang antrian (QL) $44.00 \mathrm{~m}$. Pendekat Barat 2 derajat kejenuhan (DS) 0.47, panjang antrian (QL) $29.00 \mathrm{~m}$. Sedangkan simpang tiga bersinyal pada jam puncak sore pada pendekat Utara derajat kejenuhan (DS) 0.20, panjang antrian (QL) $18.00 \mathrm{~m}$. Pendekat Selatan derajat kejenuhan (DS) 0.69, panjang antrian (QL) $52.50 \mathrm{~m}$.
Pendekat Barat 1 derajat kejenuhan (DS) 0.56, panjang antrian (QL) $44.00 \mathrm{~m}$. Pendekat Barat 2 derajat kejenuhan (DS) 0.42 , panjang antrian (QL) $29.00 \mathrm{~m}$. Nilai derajat kejenuhan belum melebihi batas toleransi yang diizinkan dimana DS $<0,8$, sehingga masih relatif mampu melayani pergerakan arus lalu lintas simpang tiga bersinyal.

Berdasarkan uraian kinerja ruas jalan koridor $1(2 / 2 \mathrm{~TB})$, ruas jalan koridor $2(4 / 2$ B) dan simpang tiga bersinyal pada masingmasing pendekat, nilai derajat kejenuhan belum melebihi batas toleransi yang diizinkan dimana DS $<0,8$, dengan demikian masih mampu melayani pergerakan arus lalu lintas jaringan jalan Pangeran Trunojoyo pada saat ini.

\section{KESIMPULAN}

- Jam puncak terjadi bersamaan pada pukul $06.45-07.45$.

- Kinerja ruas Jl. Pangeran Trunojoyo koridor $1(2 / 2 \mathrm{~TB})$ nilai derajat kejenuhan (DS) 0,59 dengan kecepatan sesungguhnya (V) $35 \mathrm{~km} / \mathrm{jam}$.

- Kinerja ruas Jl. Pangeran Trunojoyo koridor 2 (4/2 B) nilai derajat kejenuhan (DS) $\quad 0.30$, dengan kecepatan sesungguhnya (V) $50 \mathrm{~km} / \mathrm{jam}$ pada jalur 1 (S - U) dan DS 0.29, V $56 \mathrm{~km} / \mathrm{jam}$ pada jalur 2 (U - S).

- Kinerja simpang tiga bersinyal nilai derajat kejenuhan (DS) maksimum 0.71 terjadi pada pendekat Selatan, dengan panjang antrian (QL) $55.00 \mathrm{~m}$.

\section{DAFTAR PUSTAKA}

Alamsyah, Alik Ansyori , 2005. Rekayasa Lalu-lintas. Malang : UMM Press.

Direktorat Bina Jalan Kota. 1997. Manual Kapasitas Jalan Indonesia (MKJI). Jakarta: Direktorat Jenderal Bina Marga, Direktorat Bina Jalan Kota.

Khisty, Jotin dan B. Kent Lall. 2003 Jilid 2. Edisi 3. Dasar-Dasar Rekayasa Transportasi. Terjemahan oleh : Hilarius Wibi Hardani, ST, M.M, 2006. Jakarta : Penerbit Erlangga.

Morlok, Edward K. 1978. Pengantar dan Perencanaan Transportasi. Terjemahan oleh : Ir. Johan Kelanaputra Hainim. 1995. Jakarta : Penerbit Erlangga. 
Munawar, Ahmad, 2006, Manajemen Lalu Lintas Perkotaan, Cetakan Kedua, Yogyakarta : Penerbit Beta Offset.

Oglesby, C.H dan Hicks, R.G, 1982. Teknik Jalan Raya, Edisi Keempat, Jilid 1. Terjemahan Purwo Setianto. 1993. Jakarta : Penerbit Erlangga.

Peraturan Menteri Perhubungan Republik Indonesia No. PM 96 Tahun 2015 Tentang Manajemen dan Rekayasa Lalu Lintas.

Tamin, Z Ofyar. 2000. Perencanaan dan Pemodelan Transportasi - Edisi Kedua. Bandung : Penerbit ITB.

Undang Undang No. 38 Tahun 2004 Tentang Jalan. 